\title{
Spatial variability of epifaunal communities in the North Sea in relation to sampling effort
}

\author{
Hermann Neumann · Siegfried Ehrich • Ingrid Kröncke
}

Received: 30 July 2007 / Revised: 4 February 2008 / Accepted: 5 February 2008 / Published online: 29 February 2008

(C) Springer-Verlag and AWI 2008

\begin{abstract}
Benthic epifauna was sampled in six areas from the German Bight towards the Norwegian Sea using a 2-m standard beam trawl. Nine replicates were taken in each area and year from 1999 to 2006 . This data set (60-67 replicates per area) was used to describe the spatial variability in local species composition and to assess the effect of increasing sampling effort on species richness and community structure. Our results confirmed the importance of the 50-m depth contour for the separation of benthic fauna in the North Sea. Low species richness, sparse sessile fauna and high abundances of scavenging species such as Asterias rubens, Liocarcinus holsatus, Astropecten irregularis and Ophiura albida were characteristic of the low-water area south of the 50-m contour. Differences in community structure were less conspicuous in deeper waters north of the 50-m contour, but distribution patterns and abundances of single species such as Echinus elegans, Hyalinoecia tubicola, Ophiothrix fragilis, Scaphander lignarius as well as several hermit crabs resulted in well-defined epifaunal communities. One replicate caught $17-28 \%$ of the species found in 60-67 samples and was sufficient to separate the community in the German Bight from those in the central and northern North Sea by using multidimensional scaling. Nine replicates sampled a proportion of $53-60 \%$ and
\end{abstract}

Communicated by H.-D. Franke.

H. Neumann $(\bowtie) \cdot$ I. Kröncke

Department for Marine Research, Senckenberg Institute,

Südstrand 40, 26382 Wilhelmshaven, Germany

e-mail: hneumann@senckenberg.de

\section{S. Ehrich}

Federal Research Centre for Fisheries, Institute for Sea Fisheries, Palmaille 9, 22767 Hamburg, Germany provided additional information on the spatial variability of community structure in the central and northern North Sea. Our study indicates that appropriate replication enhances the quality of the data and can partly overcome the constraints of sampling with a $2-\mathrm{m}$ beam trawl. This might be helpful for future monitoring programmes.

Keywords Epifauna $\cdot$ Community structure $\cdot$ Species accumulation curves $\cdot$ Multidimensional scaling (MDS) . North Sea

\section{Introduction}

Epifauna is a major food resource for fishes (Braber and De Groot 1973; Klemetsen 1993; Bowman et al. 2000), birds and seals (Lydersen et al. 1989). First spatial investigations on epifauna communities in the North Sea were carried out by Dyer et al. (1982, 1983), resulting from the analysis of fisheries' by-catch. Since then epifaunal communities in different parts of the North Sea and the entire North Sea have been investigated and described by several authors (Basford et al. 1989; Frauenheim et al. 1989; Duineveld and van Noort 1990; Jennings et al. 1999; Rees et al. 1999; Zühlke et al. 2001a; Callaway et al. 2002). These investigations focused on the epifaunal large-scale distribution patterns and the environmental factors related to these patterns. The studies generally supported the results of Glèmarec (1973) who established three benthic regions in the North Sea separated by the 60- and 100-m depth contours. Several environmental factors such as depth, temperature, sediment composition and largescale hydrodynamic phenomena were regarded to be responsible for the distribution patterns of the North Sea epifauna.

Most of the existing studies were based on large-scale surveys with large-scale sampling resolution and single 
replicates, leading to underestimations in abundance and biomass, especially as epifauna is sampled with a $2-\mathrm{m}$ beamtrawl or dredges (Kaiser et al. 1994; Reiss et al. 2006). Thus, a small-scale sampling design with higher numbers of replicates in a smaller area is necessary to study benthic processes as well as anthropogenic effects on the benthic communities such as pollution, fisheries' impact or climate change. The German Small-scale Bottom Trawl Survey (GSBTS) was initiated in 1987 to provide high resolved process-oriented information to large-scale fishery surveys like the "International Bottom Trawl Survey (IBTS)". The GSBTS was supplemented by hydrographical measures and nutrient analysis and since 1998 was accompanied by benthic studies. Sampling took place each summer in areas of $10 \times 10$ nautical miles, the so-called Boxes, which were regularly distributed over the entire North Sea (Ehrich et al. 2007, for further information). Nine replicates were taken in each Box and year for benthic investigations so that up to now a total of 60-67 samples were available for each of the Boxes.

The specific objectives of this study were (a) to describe the spatial variability in species composition of the epifaunal communities in six areas (Boxes) of the North Sea, and (b) to assess the effect of increasing numbers of replicates on the number of species (species richness) and the community structures.

\section{Material and methods}

Epifauna sampling took place in the six Boxes A, B, C, D, $\mathrm{L}$ and $\mathrm{M}$ (each $10 \times 10 \mathrm{~nm}$ ) of the "German Small-Scale Bottom Trawl Survey (GSBTS)" (Ehrich et al. 2007) every July and August, in years 1999-2006 with FRV Walter Herwig III (Fig. 1).

Beam trawl sampling

Epifauna was sampled with a standardized $2 \mathrm{~m}$ beam trawl made of galvanized steel with a chain matt attached. The beam trawl was fitted with a $20-\mathrm{mm}$ net and a cod end of $4 \mathrm{~mm}$ mesh size. A Scanmar depth finding sonar was attached to the top of the net just behind the steel beam to determine the exact time and position of contact with the seabed. From the moment of contact the beam was towed with a speed of about 1.5-2 knots for $5 \mathrm{~min}$. In total, 384 hauls (60-67 replicates per Box) were run from 1999 to 2006. If possible, nine replicates were taken in each Box and year.

\section{Sample treatment}

Samples were sieved over $5 \mathrm{~mm}$ mesh size and epibenthic fauna was separated from the remains. The majority of

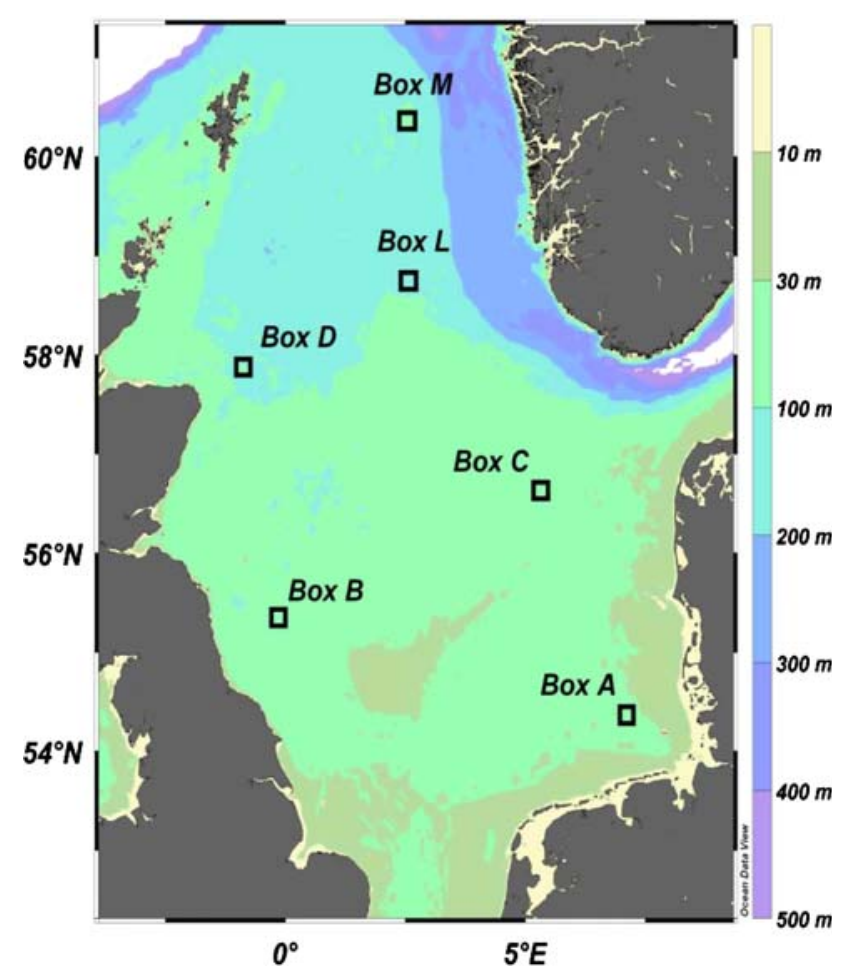

Fig. 1 Location and depth of the study areas in the North Sea (Boxes A, B, C, D, L, M)

species were identified on board. Unidentified species were preserved in a $4 \%$ seawater formalin solution for later identification in the laboratory. Abundance and wet weight of the free-living epifauna was determined using a motioncompensated marine scale (Pols) with an accuracy of $1 \mathrm{~g}$. Modular epifauna were recorded as present or absent and, if possible, weighed. All animals were identified on the lowest possible taxonomic level.

Data analysis

Epifauna catches were standardised to a tow length of $250 \mathrm{~m}$ (area sampled $=500 \mathrm{~m}^{2}$ ). Species were separated into free-living and sessile epifauna. Species numbers were analysed as total number of species (species richness) recorded in the Boxes during the study period. Smoothed species accumulation curves were calculated to assess the maximum species number per Box and the effects of a higher number of replicates on the species richness. Nonmetric multidimensional scaling (MDS) in the PRIMER v6 package (Plymouth Marine Laboratory) was used based on presence/absence and fourth root transformed abundance data. MDS ordination plots were calculated for both transformations using one and nine (+mean) replicates per Box in 1999, 2003 and 2006, and additionally all taken replicates per Box (+mean) to investigate the effects of a higher sampling effort on the MDS ordination. Data similarities 
between the Boxes were calculated using the Bray-Curtis coefficient. ANOSIM randomisation tests were performed to test the differences in the community composition of the Boxes $\left(\mathrm{H}_{0}=\right.$ no differences in community composition). Species which were predominantly responsible for the similarity within clusters were determined with the PRIMER program SIMPER.

\section{Results}

A total of 275 species were recorded in 384 samples; 166 were classified as free-living and 109 as sessile species. Table 1 gives the frequency of occurrence and the mean abundance per $500 \mathrm{~m}^{2}$ of the dominant species in each Box.

Species numbers and taxonomic groups

Generally, the total number of species was highest in the northern Box L with 120 taxa, but was also high in the Boxes B, D and M (114, 116 and 115 Taxa). The lowest number of species occurred in Box A with 53 taxa (Fig. 2). Thus, the total species number in the deeper Boxes (depth between $73 \mathrm{~m}$ in Box B and $110 \mathrm{~m}$ in Box L) was about twice as high as in the shallow Box A (depth $40 \mathrm{~m}$ ). Species number of sessile and free-living fauna, respectively, coincided with the pattern of total species numbers (Fig. 2). For both groups, lowest values were found in the Boxes A and C. However, the highest number of free-living species was recorded in Boxes $\mathrm{L}$ and $\mathrm{M}$ off the Norwegian coast (81 and 79 taxa), while highest numbers of sessile species were recorded in Boxes B and D off the British coast (46 and 49 taxa). Most of the sessile fauna belonged to the Hydrozoa and Bryozoa. A high species number of Bryozoa (17 taxa) was found in Box B and of Hydrozoa in Box D (17 taxa) (Fig. 3). In each Box species number of free-living fauna was dominated by Crustacea and Echinoderma (Fig. 4). In Boxes A and L, the species numbers of the Gastropoda ( 8 and 18 species, respectively) were somewhat higher than those of the Echinodermata (6 and 17 species, respectively).

\section{Spatial distribution of species}

Generally, sea stars (Asterias rubens; Astropecten irregularis) and hermit crabs (Pagurus bernhardus; P. pubescens; $P$. prideaux; Anapagurus laevis) were the dominant species in the Boxes (Table 1). However, mean abundance of these species was highly variable. The brittle star Ophiura albida (Box A) and the sea urchin Echinus elegans (Box L) were common species and occurred in extremely high abundances in Boxes A and $\mathrm{L}$, respectively. The only common sessile species were the anthozoans Epizoanthus incrustatus (Boxes B and D) and Adamsia carcinopadus, the sponge Suberites ficus (Box M) as well as the sea squirt Ascidiella sp. (Boxes L and M). Epizoanthus incrustatus and Adamsia carcinopadus were always associated with hermit crabs and could thus regarded as "free-living" species.

Asterias rubens, Astropecten irregularis, Pagurus bernhardus as well as the shrimp Crangon allmanni were common species in all Boxes (Table 2). Many species such as the great spider crab Hyas coarctatus, the red whelk Neptunea antiqua, the sponge Suberites ficus or the polychaet Thelepus cincinnatus were recorded only in the Boxes deeper than $50 \mathrm{~m}$ (all Boxes except Box A). The polychaet Hyalinoecia tubicola, the shrimp Spirontocaris lilljeborgi, the sea urchin Echinus elegans or the barnacle Verruca stroemia were found only in the Boxes $\mathrm{D}, \mathrm{L}$ and $\mathrm{M}$ (depth $>100 \mathrm{~m}$ ) or Boxes $\mathrm{L}$ and $\mathrm{M}$ (Norwegian coast; depth $>100 \mathrm{~m}$ ). The masked crab Corystes cassivelaunus was recorded only in the Boxes $\mathrm{A}$ and $\mathrm{C}$ situated in low water and near the 50-m depth contour, respectively. Other species such as the brittle stars Ophiura albida (Box A) and Ophiothrix fragilis (Box C) or the opisthobranch Scaphander lignarius (Box $\mathrm{M}$ ) were found only in one Box (Fig. 2).

Species accumulation curves

The number of species (species richness) in the Boxes was found to be a function of increasing sampling effort (Fig. 5). With one replicate $17 \%$ (Box B) to $28 \%$ (Box M) of the species recorded in 60-67 replicates were caught, with nine replicates 53\% (Box A) to 60\% (Box M) (Fig. 5). The species accumulation curves did not even approach the asymptote in any Box after 60-67 replicates. The increase of species numbers after $60-67$ replicates made up only $0.2-0.6$ species per additional sample. This ratio was higher in the species-rich Boxes B, D, L, and M (0.4-0.6 species) than in the species-poor Boxes $\mathrm{A}$ and $\mathrm{C}(0.2$ species $)$ due to a higher number of rare species found in these Boxes.

Multivariate community analysis

Figures 6 and 7 provide the MDS analyses based on one, nine and the mean of nine replicates for the years 1999, 2003 and 2006 as well as 60-67 replicates and the mean of 60-67 replicates per Box for presence/absence and fourth root transformation. The MDS analyses based on one replicate per Box revealed different similarities between the communities in the Boxes in 1999, 2003 and 2006, which were also contradicting using presence/absence or fourth root transformation. The communities in the Boxes B, C, D, $\mathrm{L}$ and $\mathrm{M}$ were grouped together and were highly dissimilar 
Table 1 Frequency of occurrence, mean abundance and contribution to similarity within the Boxes of the five dominant species in Boxes $\mathrm{A}, \mathrm{B}, \mathrm{C}, \mathrm{D}, \mathrm{L}$ and $\mathrm{M}$
"Mean similarity" and "contribution to similarity" is given for presence/absence and fourth root transformed data. Sessile species are marked with an asterisk $(*)$

\begin{tabular}{|c|c|c|c|c|c|}
\hline & $\begin{array}{l}\text { Mean } \\
\text { similarity (\%) }\end{array}$ & & $\begin{array}{l}\text { Frequency } \\
(\%)\end{array}$ & $\begin{array}{l}\text { Abundance } \\
\text { (ind. } 500 \mathrm{~m}^{-2} \text { ) }\end{array}$ & $\begin{array}{l}\text { Contribution } \\
\text { to similarity }(\%)\end{array}$ \\
\hline \multirow{7}{*}{ Box A } & \multirow{7}{*}{$63 / 62$} & Asterias rubens & 100 & 132 & $15 / 24$ \\
\hline & & Liocarcinus holsatus & 100 & 42 & $13 / 13$ \\
\hline & & Ophiura albida & 94 & 672 & $13 / 18$ \\
\hline & & Astropecten irregularis & 94 & 27 & $13 / 13$ \\
\hline & & Pagurus bernhardus & 94 & 5 & $13 / 9$ \\
\hline & & Corystes cassivelaunus & 85 & 13 & $9 / 8$ \\
\hline & & All species & - & 929 & \\
\hline \multirow[t]{7}{*}{ Box B } & \multirow[t]{7}{*}{$50 / 52$} & Pagurus bernhardus & 97 & 8 & $10 / 17$ \\
\hline & & Asterias rubens & 97 & 6 & $10 / 16$ \\
\hline & & Epizoanthus incrustatus* & 96 & - & 9/- \\
\hline & & Astropecten irregularis & 88 & 3 & $8 / 10$ \\
\hline & & Anapagurus laevis & 87 & 2 & $8 / 10$ \\
\hline & & Neptunea antiqua & 82 & 2 & $7 / 8$ \\
\hline & & All species & - & 40 & \\
\hline \multirow[t]{7}{*}{ Box $\mathrm{C}$} & \multirow[t]{7}{*}{$61 / 62$} & Astropecten irregularis & 100 & 44 & $7 / 14$ \\
\hline & & Asterias rubens & 100 & 7 & $7 / 9$ \\
\hline & & Buccinum undatum & 100 & 13 & $7 / 9$ \\
\hline & & Pagurus bernhardus & 100 & 13 & $7 / 10$ \\
\hline & & Colus gracilis & 88 & 7 & $5 / 6$ \\
\hline & & Luidia sarsi & 86 & 7 & $5 / 6$ \\
\hline & & All species & - & 142 & \\
\hline \multirow[t]{7}{*}{ Box D } & \multirow[t]{7}{*}{$49 / 52$} & Crangon allmanni & 98 & 64 & $9 / 22$ \\
\hline & & Anapagurus laevis & 95 & 9 & $9 / 15$ \\
\hline & & Pagurus bernhardus & 92 & 8 & $8 / 14$ \\
\hline & & Pagurus prideaux & 91 & 10 & $8 / 11$ \\
\hline & & Epizoanthus incrustatussp.* & 96 & - & $8 /-$ \\
\hline & & Adamsia carciniopados $*$ sp.* & 89 & - & $8 /-$ \\
\hline & & All species & - & 116 & \\
\hline \multirow[t]{7}{*}{ Box L } & \multirow[t]{7}{*}{$52 / 53$} & Echinus elegans & 100 & 484 & $8 / 20$ \\
\hline & & Astropecten irregularis & 100 & 44 & $8 / 15$ \\
\hline & & Ascidiellasp.* & 100 & 5 & $6 /-$ \\
\hline & & Anapagurus laevis & 97 & 7 & $8 / 9$ \\
\hline & & Pagurus pubescens & 90 & 3 & $7 / 7$ \\
\hline & & Thelepus cincinnatus & 85 & 2 & $6 / 6$ \\
\hline & & All species & - & 602 & \\
\hline \multirow[t]{7}{*}{ Box M } & \multirow[t]{7}{*}{$63 / 60$} & Anapagurus laevis & 100 & 30 & $5 / 10$ \\
\hline & & Pagurus pubescens & 100 & 28 & $5 / 10$ \\
\hline & & Pagurus prideaux & 100 & 12 & $5 / 8$ \\
\hline & & Ascidiella sp.* & 100 & 5 & $3 /-$ \\
\hline & & Adamsia carciniopadus* & 98 & 11 & $5 /-$ \\
\hline & & Suberites ficus* & 93 & - & $5 /-$ \\
\hline & & All species & - & 177 & \\
\hline
\end{tabular}

to the community in Box A in 1999 (presence/absence) and 2003 (fourth root). In contrast, all communities in the Boxes were rather evenly distributed in 1999 (fourth root) and 2006 (presence/absence). Additionally, a high similarity was found between the communities in Boxes $\mathrm{L}$ and $\mathrm{M}$ in 2003 (presence/absence), whereas Box M was grouped together with Box D in 2006 (fourth root).

The MDS analyses based on nine replicates per Box reflect similar results in 1999, 2003 and 2006 for both transformations. Additionally, the spatial similarities based on nine 


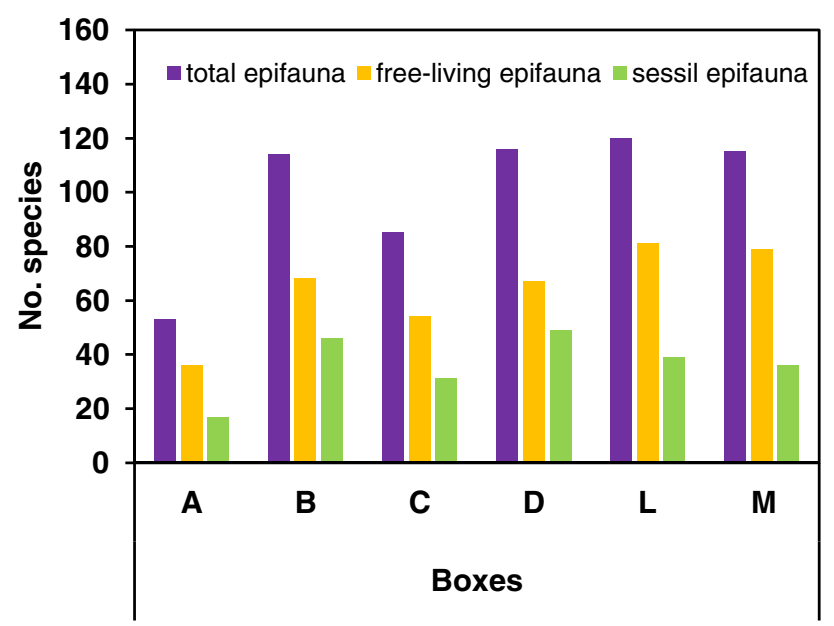

Fig. 2 Total number of species per haul for total epifauna, free-living epifauna and sessile epifauna

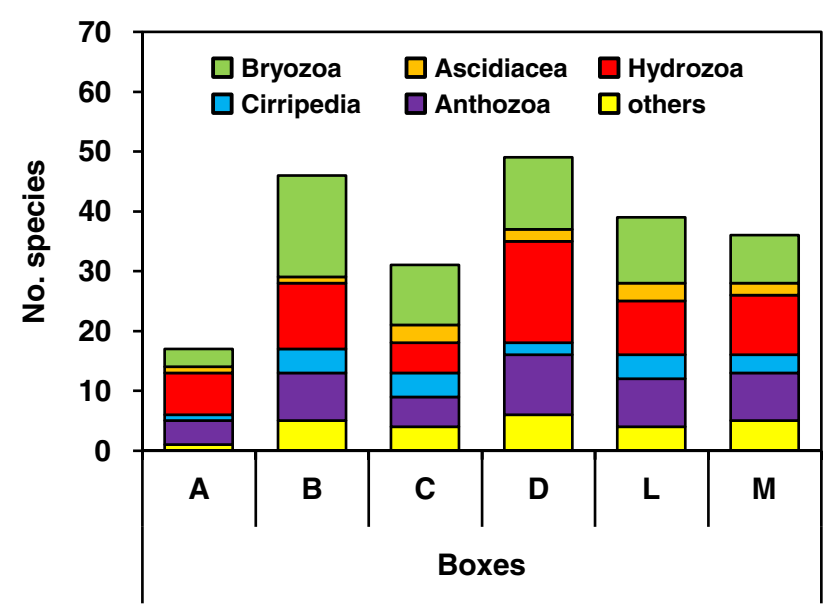

Fig. 3 Total number of sessile species per haul and taxonomic group

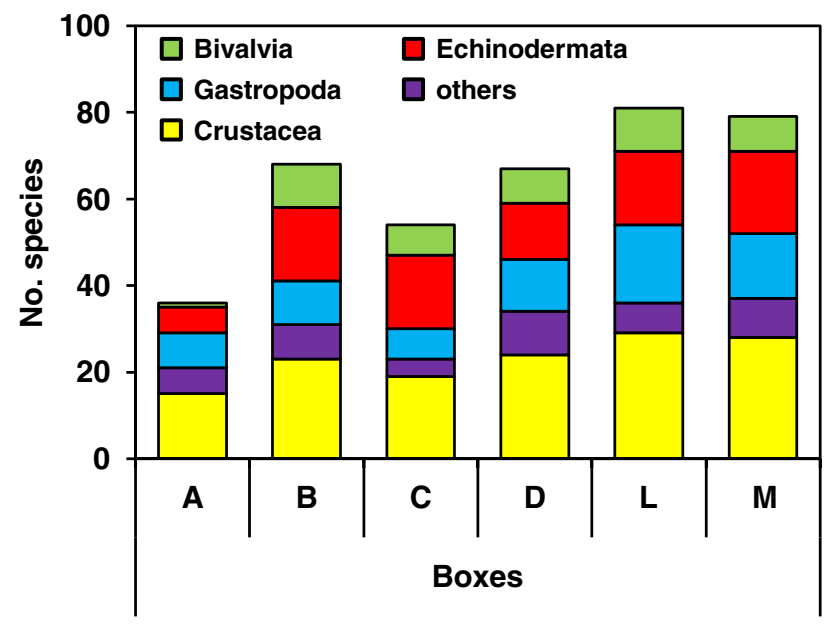

Fig. 4 Total number of free-living species per haul and taxonomic group
Table 2 Frequencies (\%) of species in the Boxes

\begin{tabular}{lllllll}
\hline & \multicolumn{7}{l}{ Boxes } & & & & \\
\cline { 2 - 7 } & $\mathrm{A}$ & $\mathrm{B}$ & $\mathrm{C}$ & $\mathrm{D}$ & $\mathrm{L}$ & $\mathrm{M}$ \\
\hline Asterias rubens & 100 & 97 & 100 & 68 & 64 & 85 \\
Astropecten irregularis & 94 & 88 & 100 & 22 & 100 & 92 \\
Crangon allmanni & 48 & 51 & 32 & 98 & 80 & 77 \\
Pagurus bernhardus & 94 & 97 & 100 & 92 & 69 & 93 \\
Anapagurus laevis & & 87 & 32 & 95 & 97 & 100 \\
Colus gracilis & & 40 & 88 & 38 & 89 & 93 \\
Hyas coarctatus & & 48 & 78 & 48 & 56 & 85 \\
Neptunea antiqua & & 82 & 82 & 51 & 72 & 93 \\
Suberites ficus* & & 64 & 80 & 78 & 23 & 93 \\
Thelepus cincinnatus & & 60 & 31 & 26 & 85 & 80 \\
Hyalinoecia tubicola & & & & 63 & 46 & 68 \\
Spirontocaris lilljeborgi & & & & 22 & 30 & 28 \\
Echinus elegans & & & & & 100 & 52 \\
Verruca stroemia* & & & & & 21 & 32
\end{tabular}

Ophiura albida

94

Leptasterias muelleri $\quad 40$

Ophiothrix fragilis $\quad 75$

Scaphander lignarius

42

$\begin{array}{lll}\text { Corystes cassivelaunus } & 85 & 77\end{array}$

Frequencies below $8 \%$ are not shown. Sessile species are marked with an asterisk $(*)$

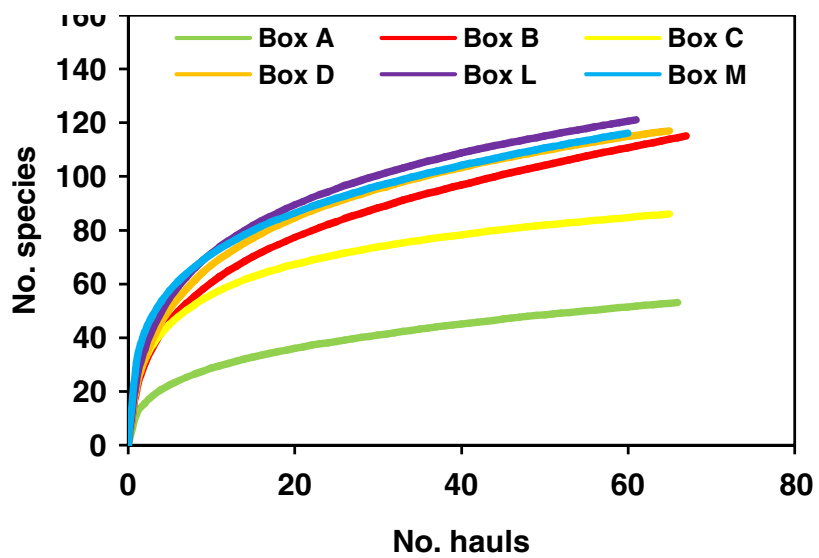

Fig. 5 Species accumulation curves for the Boxes A, B, C, D, L and M

replicates coincide with those based on 60-67 replicates per Box. They reveal a high dissimilarity of the community in Box A to all other Boxes, but a similar community structure in Boxes B and C in the central North Sea as well as in Boxes D, L and $\mathrm{M}$ in the northern North Sea. They also show a rather high small-scale variability within a single Box, but the communities were significantly different as confirmed by the ANOSIM test (Table 3 ). The ANOSIM test based on 60-67 replicates and provided $R$ values of 0.83 


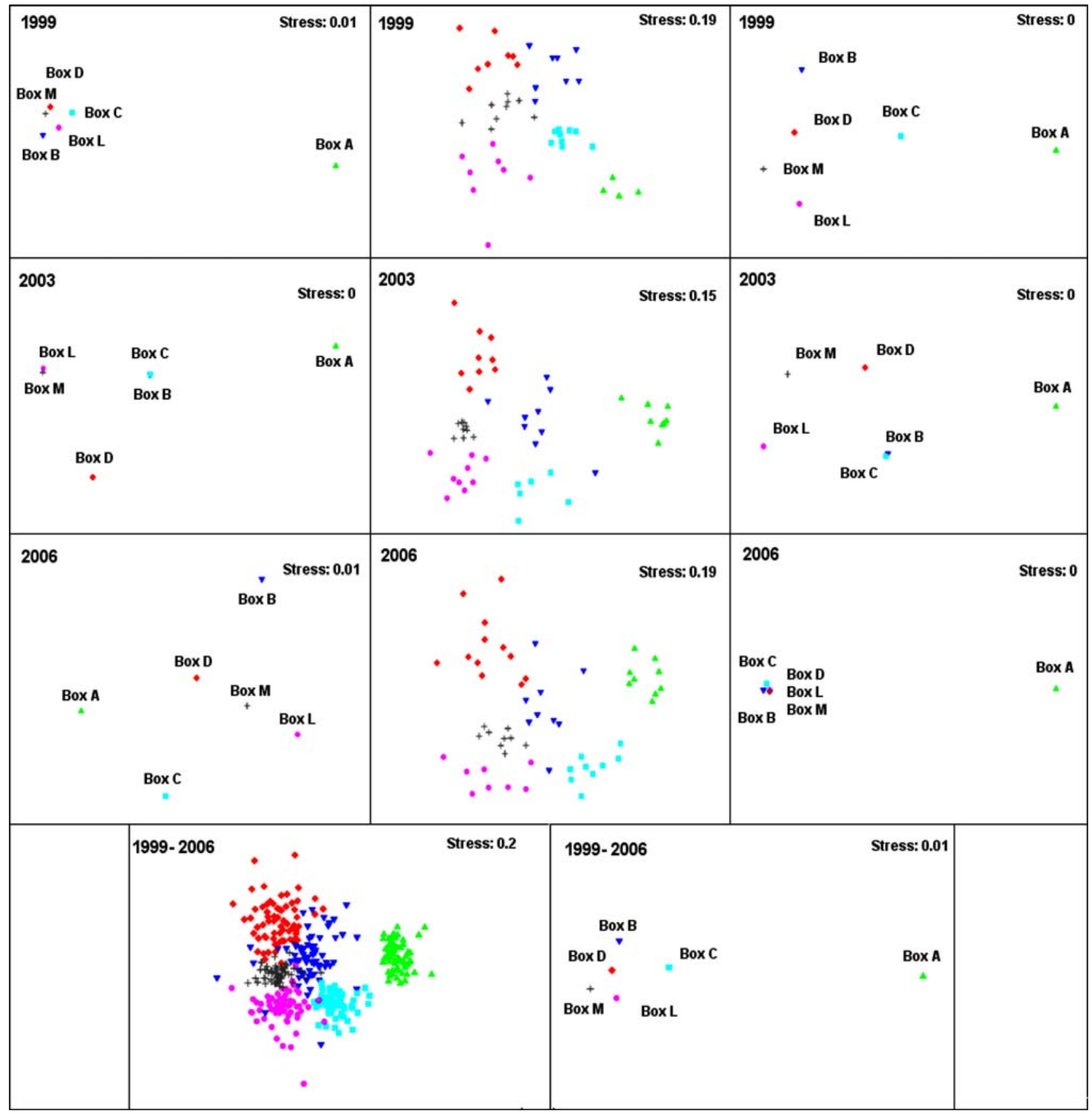

Fig. 6 Multidimensional scaling (MDS) plots based on presence/absence transformed data of the Boxes A, B, C, D, L and M. MDS were calculated using one replicate (left), nine replicates (centre), and the mean of nine replicates (right) in the years 1999, 2003 and 2006; as well as using 60 to 67 replicates (bottom left) and the mean of 60 to 67 replicates (bottom right) to 0.94 at $P=0.001\left(\mathrm{H}_{0}\right.$ can be rejected $)$, indicating that there were significant differences between the communities in the Boxes A, B, C, D, L and M (Table 3). The average similarities between replicates within the Boxes varied between $49 \%$ and $63 \%$ (based on 60 to 67 replicates); species contributing to these similarities are listed in Table 1.

The MDS analyses based on the mean of nine and 60-67 replicates, respectively, revealed almost the same spatial pattern as the non-averaged nine and 60-67 replicates for both transformations. However, in 2006 (presence/absence) and 1999 (fourth root), this spatial pattern became evident only if more than one replicate per Box was used. Generally, nine and more replicates per Box as well as their means provide similar spatial patterns using multidimensional scaling and thus provide better results than single replicates per Box. 


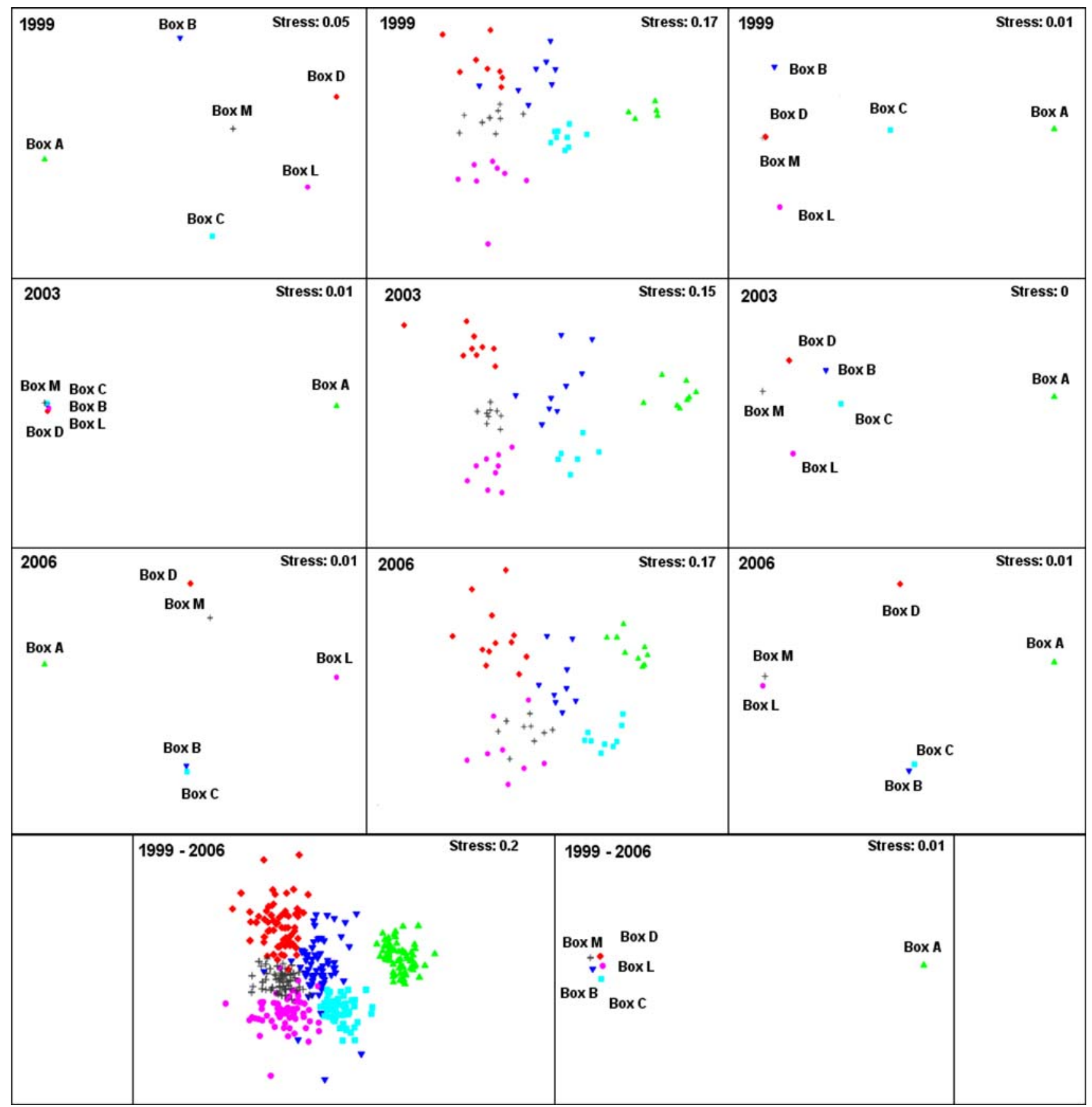

Fig. 7 Multidimensional scaling (MDS) plots based on $4^{\text {th }}$ root transformed data of the Boxes A, B, C, D, L and M. MDS were calculated using one replicate (left), nine replicates (centre), and the mean of nine

\section{Discussion}

The number of epifaunal species was generally lower in the southern North Sea than in central and northern areas. Also distribution patterns of single species found already in previous studies were reflected in our results (Table 2). For example, the limitation of the masked crab Corystes cassivelaunus and the brittle star Ophiura albida to an area north of the Dogger Bank (Box A; Table 2) was already replicates (right) in the years 1999, 2003 and 2006; as well as using 60 to 67 replicates (bottom left) and the mean of 60 to 67 replicates (bottom right)

mentioned by Frauenheim et al. (1989). Zühlke et al. (2001a) found the polychaet Hyalinoecia tubicola limited to an area north of the 80-m contour (Box D, L and M; Table 2), and the polychaet Thelepus cincinnatus, the sponge Suberites ficus as well as the spider crab Hyas coarctatus and the hermit crab Anapagurus laevis limited to an area north of the 50-m contour (all Boxes except Box A; Table 2). Species such as the sea stars Asterias rubens and Astropecten irregularis as well as the hermit crab Pagurus bernhardus were 
Table 3 ANOSIM results of presence/absence and 4th root transformed data

\begin{tabular}{llcclcc}
\hline & \multicolumn{3}{l}{ Presence/absence } & \multicolumn{4}{l}{ Fourth root } \\
\hline Nine replicates & 1999 & 2003 & 2006 & 1999 & 2003 & 2006 \\
& 0.83 & 0.91 & 0.90 & 0.90 & 0.94 & 0.94 \\
60-67 replicates & $1999-2006$ & & $1999-2006$ & \\
& 0.83 & & & 0.85 & \\
& & & & &
\end{tabular}

$P<0.001$

frequently found in all Boxes (Table 2) and their ubiquity in the North Sea was consistent with distribution patterns found in previous studies (Frauenheim et al. 1989; Zühlke et al. 2001a; Callaway et al. 2002).

Spatial community structure

Glèmarec (1973) introduced the concept of the three infaunal étages in the North Sea, which largely correspond with the areas separated by the 50, 100 and 200-m depth contour. This concept for the benthic infauna was confirmed and differentiated by Künitzer et al. (1992). Also, most epifaunal large scale studies confirmed the importance of this depth contours for the separation of epifaunal communities in the North Sea (Dyer et al. 1983; Basford et al. 1989; Frauenheim et al. 1989; Duineveld and van Noort 1990; Jennings et al. 1999; Rees et al. 1999; Zühlke et al. 2001a; Callaway et al. 2002). Especially, the 50-m depth line was the most conspicuous boundary for epifaunal communities separating the southern and central-northern North Sea (Callaway et al. 2002). The 50-m depth contour closely matches the boundary between mixed and stratified waters and more abrupt changes in the biotic and abiotic environment in this area are most likely responsible for the distinct faunal separation. The distinctness of the 50-m contour is reflected in our results by greater differences in community structure between Box A and the remaining Boxes as shown by MDS analyses, even those based on one replicate per Box (Fig. 6, 7). In general, higher abundances of scavenging species, the scarcity of sessile fauna and the low species richness in Box A contribute most to these differences (Table 1; Fig. 2), and these results coincided with several previous large-scale studies (Jennings et al. 1999; Zühlke et al. 2001a; Callaway et al. 2002). One of the four different communities in the southern North Sea identified by Callaway et al. (2002) was characterised by the scavenging species Asterias rubens, Liocarcinus holsatus, Ophiura albida, Astropecten irregularis, Pagurus bernhardus and Corystes cassivelaunus, which were in turn the most frequently found species in Box A (Table 1). Similar to our results Hinz et al. (2004) and Reiss and Kröncke (2004) found high abundances of Asterias rubens and Ophiura albida in the area of Box A. The sea urchin Psammechinus miliaris was found to be a characteristic species of the south (Dyer et al. 1983; Cranmer 1985; Jennings et al. 1999; Callaway et al. 2002), but was scarce in Box A. More frequent records in the beginning of this study indicate the disappearance of this species in Box A.

The differences in community structure between the Boxes north of the 50-m contour only becomes evident if nine or more replicates are used. Basford et al. (1989) mentioned the importance of the 100-m depth contour since it separates the more stable northern environment from the more variable central area. In our study it separates the Boxes $\mathrm{B}$ and $\mathrm{C}$ in the central North Sea from the Boxes D, L and M in the northern North Sea. But the MDS analysis revealed a less obvious separation of the communities in the central and northern North Sea. However, the results of the ANOSIM analysis and the high mean similarity of the replicates per Box (49-63\%) indicate different communities in the five Boxes. But species composition partly differs from that determined in corresponding parts of the North Sea by previous large-scale studies.

Box C (mean depth $60 \mathrm{~m}$ ) was a species-poor Box providing an intermediate state between the southern and the central North Sea (Fig. 2). High abundances of the sea star Astropecten irregularis as well as frequent records of gastropods such as Buccinum undatum and Neptunea antiqua or species such as the spider crab Hyas coarctatus were found (Table 1), which is characteristic of the central North Sea (Basford et al. 1989; Jennings et al. 1999; Callaway et al. 2002). But additionally, the masked crab Corystes cassivelaunus was a common species in Box C (Table 2), which is a characteristic species of the southern North Sea (Callaway et al. 2002). The brittle star Ophiothrix fragilis was exclusively found in Box C. The intermediate state of Box $\mathrm{C}$ was also reflected in the results of the MDS (Figs. 6, 7 ), particularly in those based on the mean of nine or more replicates.

Low abundances were characteristic of the slightly deeper Box B (mean depth $75 \mathrm{~m}$ ), which was situated in the central North Sea near the British coast. Mean abundance reached 40 individuals $/ 500 \mathrm{~m}^{2}$ in 67 replicates and the hermit crab Pagurus bernhardus was the most abundant species $\left(8\right.$ ind. $/ 500 \mathrm{~m}^{2}$ ). In general, low densities of species and high numbers of sessile fauna were characteristic of the central part of the North Sea (Zühlke et al. 2001a) coinciding with our results (Table 1; Figs. 2, 5). But species distribution was partly different. Species such as Hyalinocia tubicola and Echinus sp. were described as characteristic of the central North Sea by Callaway et al. (2002), but were rare in our study in Box $\mathrm{B}$ (occurrence $<8 \%$; Table 2). Additionally, the area surrounding Box B was defined as "NW North Sea gravelly group" by Rees et al. (1999), but 
characteristic species such as Hyas coarctatus or Colus gracilis were found rather irregular in Box B, whereas Astropecten irregularis as a common species in Box B was not found by Rees et al. (1999).

The community in Box D also provided an intermediate state between the central and the northern North Sea. High numbers of sessile fauna as in Box B, together with the frequent occurrence of species such as Epizoanthus incrustatus leads to suspect that Boxes $\mathrm{B}$ and $\mathrm{D}$ belong to a community in front of the British coast, which was defined as "NW North Sea gravelly group" by Rees et al. (1999). Furthermore, the shrimp Crangon allmanni, the most abundant and frequent species in Box D, was described by Jennings et al. (1999) as a characteristic species of the central North Sea and was also found in high abundances by Basford et al. (1989) and Zühlke et al. (2001a) in the area of Box D. On the other hand, the hermit crab Pagurus prideaux is a northerly distributed species (Basford et al. 1989; Zühlke et al. 2001a) and was a characteristic species of Boxes D and M (Table 1).

High abundances of sea urchins of the genus Echinus were mentioned on the edge of the Norwegian channel by Ursin (1960), Dyer et al. (1983), Cranmer (1985), Basford et al. (1989) and Zühlke et al. (2001a) what corresponds with our results in Box L (Table 1). We identified Echinus elegans in Boxes $\mathrm{L}$ and $\mathrm{M}$, but the cited authors found also Echinus acutus or its variations E. a. flemmingii (Forbes) and E. a. norvegicus (Duben and Koren). Gage et al. (1986) mentioned that it is usually not possible to separate smallest specimens of E. a. var. norvegicus and E. elegans. Additionally, the hybridisation of these species might be possible (Mortensen 1977; Zühlke et al. 2001b). The hermit crab Pagurus pubescens and the sea squirts of the genus Ascidiella were common species in Boxes L and $\mathrm{M}$ and were found to be more north easterly distributed species (Basford et al. 1989; Zühlke et al. 2001a). The opisthobranch Scaphander lignarius is a specific species of Box $\mathrm{M}$ and were also found in high abundances in the area of this Box by Basford et al. (1989).

The effect of higher replication on species number

The research on epifaunal communities in the North Sea started in the 1980s (Dyer et al. 1982; Dyer et al. 1983). Since then, several authors described the distribution of epifaunal species in the North Sea on large-scale surveys (Frauenheim et al. 1989; Duineveld and van Noort 1990; Jennings et al. 1999; Zühlke et al. 2001a; Callaway et al. 2002). A wide range of sampling gears and methods as well as different data analyses were used in these studies. For example, Basford et al. (1989) sampled the epifauna of the northern North Sea using a 2-m Agassiz trawl, while Dyer et al. (1983) used a commercial otter trawl of the Cranton type. The use of small semi-quantitative beam trawls and the standardizations of the sampling methods described by Jennings et al. (1999) were a useful improvement. The standard 2-m beam trawl provided better qualitative results than larger otter trawls (Jennings et al. 1999), and the subsequent use has made the following studies easier to compare. However, catching efficiency of the 2-m beam trawl is low and varied greatly between species. Reiss et al. (2006) found catching efficiencies varying between $9 \%$ (Liocarcinus holsatus) and $72 \%$ (Processa spp.) for the same 2-m beam trawl as used in this study. Thus, the abundance of epifauna will be underestimated by a factor of 1.4 up to 11 . Therefore, trawls were generally regarded as semi-quantitative gears, which may be used for qualitative sampling (Eleftheriou and Moore 2005). Appropriate replication can partly overcome the low catching efficiency of the 2-m beam trawl and, thus, improve the quality of the data. But little is known about the effect of increasing numbers of replicates on the quality of data sampled with beam trawls. For benthic infauna, Rumohr et al. (2001) found that more than ten replicates with a van Veen grab are required in order to include more than two-thirds of the species found in 70 replicates. This partly corresponds with our results for the 2-m beam trawl even though the results depend on the area sampled. We need 11 (Box C) to 19 (Box A) replicates in order to include two-thirds of the species found in 60-67 replicates, probably due to the larger sampling area in our study compared to those of Rumohr et al. (2001) and a better qualitative sampling by the van Veen grab compared to the 2-m beam trawl. The numbers of replicates are often a problem of time and financial constraints. Therefore, most large-scale studies used a low-replicated sampling strategy in favour of a great sampling grid. For example, Callaway et al. (2002) took one to three samples in each 139 ICES rectangles of $30 \times 30$ nautical miles covering the whole North Sea. They found 5-19 species in the area of Box A while we found 28 species in 9 replicates and 53 species in 66 replicates. This indicates an underestimation of species richness by Callaway et al. (2002) by a factor of $2.8-11$. However, temporal variability of species richness in the Boxes is not completely excluded in our study what can bias the species accumulation curves. Neumann (2006) found an increasing species richness in Box A from 1999 to 2004 while it were rather constant in Boxes C and L over the same period. Thus, the estimation of species richness could be slightly over- or under estimated in the present study, particularly those in Box A.

The effect of higher replication on community structure

The method of non-metric multidimensional scaling (MDS) was used in benthic studies to analyse spatial and temporal community patterns (Reiss and Kröncke 2001; Hinz et al. 
2004; Reiss and Kröncke 2004). The MDS technique attempts to place samples on a "map" in such a way that distances between samples agree with the rank order of the corresponding (dis)similarities (Clarke and Warwick 2001). Thus, it is necessary to sample a representative community assemblage to get an adequate "map" of the temporal or spatial differences between communities. Our results show that this can hardly be achieved with one replicate due to the qualitative and quantitative constraints of the 2-m beam trawl described above. Thus, the MDS plots based on one replicate per Box revealed completely inconsistent spatial patterns of the communities in the Boxes. On the other hand, even those MDS show the distinctness of the 50-m depth contour expressed by the high dissimilarity of Box A to all other Boxes. Thus, even one replicate could be sufficient where the samples are expected to divide into welldefined groups. But a consistent spatial pattern between the communities of the Boxes was only revealed if nine or more replicates were used. Here, the MDS plots again show the high dissimilarity of Box A to the other Boxes but additionally a temporal consistent spatial pattern of the boxes north of the 50-m contour. The specific species distribution in the Boxes leads to well-defined communities as confirmed by the ANOSIM analysis, and the less obvious separation of these communities by the MDS analysis coincides with less clearly defined faunal boundaries in the northern and central North Sea mentioned by Callaway et al. (2002). Additionally, the MDS plots based on nine or more replicates were similar for fourth root (quantitative) and presence/absence (qualitative) transformation indicating still useful quantitative results for $2-\mathrm{m}$ beam trawls with an appropriate replication.

Acknowledgments We thank the captains and crews of FRV "Walther Herwig III" for their help with sampling. The data analysis was funded by the EWE-Foundation (Oldenburg), which is kindly acknowledged.

\section{References}

Basford DJ, Eleftheriou A, Raffaelli D (1989) The epifauna of the northern North Sea $\left(56^{\circ}-61^{\circ} \mathrm{N}\right)$. J Mar Biol Assoc UK 69:387-407

Bowman RE, Stillwell CE, Michaels WL, Grosslein D (2000) Food of Northwest Atlantic Fishes and Two Common Species of Squid. National Oceanic and Atmospheric Administration (NOAA), Technical Memorandum NMFS-NE-155, Woods Hole,

Braber L, De Groot SJ (1973) The food of five flatfish species (Pleuronetiformes) in the southern North Sea. Neth J Sea Res 6:163-172

Callaway R, Alsvag J, de Boois I, Cotter J, Ford A, Hinz H, Jennings S, Kröncke I, Lancaster J, Piet G, Prince P, Ehrich S (2002) Diversity and community structure of epibenthic invertebrates and fish in the North Sea. ICES J Mar Sci 59:1199-1214

Clarke KR, Warwick RM (2001) Change in marine communities: an approach to statistical analysis and interpretation. Plymouth Marine Laboratory, Plymouth
Cranmer GJ (1985) Recent investigation into the distribution of regular echinoids in the North Sea. J Mar Biol Assoc UK 65:351-357

Duineveld GCA, van Noort GJ (1990) Geographical variation in the epifauna of the southern North Sea and adjacent regions, vol 9. ICES CM 1990/MINI, p 7

Dyer MF, Fry WG, Fry PD, Cranmer GJ (1982) A series of north sea benthos surveys with trawl and headline camera. J Mar Biol Assoc UK 62:297-313

Dyer MF, Fry WG, Fry PD, Cranmer GJ (1983) Benthic regions within the North Sea. J Mar Biol Assoc UK 63:683-693

Ehrich S, Adlerstein S, Brockmann U, Floeter J, Garthe S, Hinz H, Kröncke I, Neumann H, Reiss H, Sell AF, Stein M, Stelzenmüller V, Stransky C, Temming A, Wegner G, Zauke GP (2007) 20 years of the German small-scale bottom trawl survey (GSBTS): a review. Senckenb Marit 37:13-82

Eleftheriou A, Moore DC (2005) Macrofauna techniques. In: Eleftheriou A, McIntyre A (eds) Methods for the study of marine benthos. Blackwell, Oxford, pp 1-418

Frauenheim K, Neumann V, Thiel H, Türkay M (1989) The distribution of the larger epifauna during summer and winter in the North Sea and its suitability for environmental monitoring. Senckenb Marit 20:101-118

Gage JD, Tyler PA, Nichols D (1986) Reproduction and growth of Echinus acutus var. norvegicus Düben \& Koren and E. elegans Düben \& Koren on the continental slope off Scotland. J Exp Mar Biol Ecol 101:61-83

Glèmarec M (1973) The benthic communities of the European North Atlantic continental shelf. Oceanogr Mar Biol Ann Rev 11:263289

Hinz H, Kröncke I, Ehrich S (2004) Seasonal and annual variability in an epifaunal community in the German Bight. Mar Biol 144:735745

Jennings S, Lancaster J, Woolmer A, Cotter J (1999) Distribution, diversity and abundance of epibenthic fauna in the North Sea. J Mar Biol Assoc UK 79:385-399

Kaiser MJ, Rogers SI, McCandless DT (1994) Improving quantitative surveys of epibenthic communities using a modified $2 \mathrm{~m}$ beam trawl. Mar Ecol Prog Ser 106:131-138

Klemetsen A (1993) The food of the long-rough dab (Hippoglossoides platessoides Limandoides Bloch) in Balsfjorden, North Norway. Sarsia 78:17-24

Künitzer A, Basford D, Craeymeersch JA, Dewarumez JM, Dörjes J, Duineveld GCA, Eeleftheriou A, Heip C, Herman P, Kingston P, Niermann U, Rachor E, Rumohr H, de Wilde PAJ (1992) The benthic infauna of the North Sea: species distribution and assemblages. ICES J Mar Sci 49:127-143

Lydersen C, Gjertz I, Weslawski JM (1989) Stomach contents of autumn-feeding marine vertebrates from Hornsund, Svalbard. Polar Rec 25:107-114

Mortensen T (1977) Handbook of the Echinoderms of the British Isles. Backhuys, Rotterdam

Neumann H (2006) Räumliche und zeitliche Variabilität unterschiedlicher Epifaunagemeinschaften in der Nordsee. Diploma thesis. Carl von Ossietzky University, Oldenburg

Rees HL, Pendle MA, Waldock R, Limpenny DS, Boyd SE (1999) A comparison of benthic biodiversity in the North Sea, English Channel, and Celtic Seas. ICES J Mar Sci 56:228-246

Reiss H, Kröncke I (2001) Spatial and temporal distribution of macrofauna in the Otzumer Balje (East Frisian Wadden Sea, Germany). Senckenb Marit 31:283-298

Reiss H, Kröncke I (2004) Seasonal variability of epibenthic communities in different areas of the southern North Sea. ICES J Mar Sci 61:882-905

Reiss H, Kröncke I, Ehrich S (2006) Estimating catch efficiency of a $2 \mathrm{~m}$ beam trawl for sampling epifauna by removal experiments. ICES J Mar Sci 63:1453-1464 
Rumohr H, Karakassis I, Jensen JN (2001) Estimating species richness, abundance and diversity with 70 macrobenthic replicates in the Western Baltic Sea. Mar Ecol Prog Ser 214:103-110

Ursin E (1960) A quantitative investigation of the echinoderm fauna of the central North Sea. Meddelelser fra Danmarks Fiskeri-Og Havundersogelser 2:1-204

Zühlke R, Alsvag J, de Boois I, Cotter J, Ehrich S, Ford A, Hinz H, Jarre-Teichmann A, Jennings S, Kröncke I, Lancaster J, Piet G,
Prince P (2001a) Epibenthic diversity in the North Sea. Senckenb Marit 31:269-281

Zühlke R, Alsvag J, de Boois I, Cotter J, Ford A, Hinz H, Jarre-Teichmann A, Jennings S, Kröncke I, Lancaster J, Piet G, Prince P (2001b) Monitoring biodiversity of epibenthos and demersal fish in the North Sea and Skagerrak. School of Biological Science, University of Wales Swansea, Swansea 